\title{
BALINESE VS LAMPUNGNESE: MEASURING ADR APPLICABILITY TO RESOLVE ETHNIC CONFLICT IN INDONESIA $^{1}$
}

\author{
Bayu Sujadmiko* \& Intan Fitri Meutia**
}

\begin{abstract}
Ethnic conflict between the villagers of Balinuraga (Balinese tribe) and the villagers of Agom and Negeri Pandaan (Lampungnese tribe) happened from October 27-29, 2012 in South Lampung, Indonesia. This horizontal conflict did not only create a massive material destruction, but also resulted in villagers' evacuation, injury, and death. 1,108 villagers were evacuated and 247 of them were children. Fourteen villagers were reported killed and nine injured. The conflict was triggered from traffic accident of two girls from Lampungnese, who was helped by villagers of Balinuraga. However, as a result of provocation among the Lampungnese after the accident, it eventually became a serious sexual harassment issue that led to civil war. The resolution of its primordial conflict has basically been done through mediation between two provoked ethnicities. Restorative justice in Indonesia, in its development, has now become the social change opinion doctrine. It means that the punishment currently implemented in the criminal justice system has not been able to achieve the goals, for both the offender and the community at large. Therefore, there is an urgency for a theoretical thought with other procedural law adopted in this model, called Alternative Dispute Resolution (ADR) as a solution concept, which is faster and simpler without having to hurt the values of justice. Conflict through democracy has been the conceptual basis of ADR. It contains ideas that include establishing joint participation among the offender, victim and community groups in solving a crime that is deemed fairly to all parties (win-win solution), therefore it is considered to be applicable for indigenous conflict resolution. ADR has principally become an effective effort done by Civilian Police in Indonesia as a solution for community justice. In general, there are four important points of mediation, which are: (1) citizen contract, (2) cultural area, (3) citizen empowerment and (4) community policing.
\end{abstract}

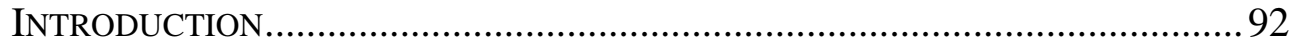

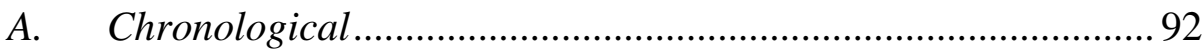

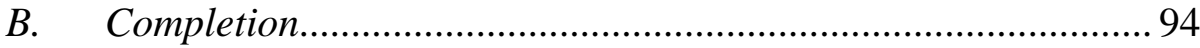

\footnotetext{
${ }^{1}$ This research was supported by Faculty of Law, Lampung University and Association of Legal Aid and Human Right Indonesia: Lampung Branch.

* Bayu Sujadmiko, Ph.D. Students at Human, Socio and Environmental Studies, Kanazawa University, Japan. His researches focus on International Law, Dispute Resolution and Private Law.

${ }^{* *}$ Intan Fitri Meutia, Lecturer at Social and Political Science, Lampung University, Indonesia. She concerns about Public Policy, Civilian Police Management and Sociological Movement.
} 
I. Restorative Justice AND Alternative Dispute Resolution IN ETHNiC

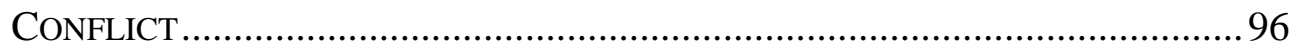

A. Restorative Justice Approach Is Solution for Social Conflict ....96

B. Alternative Dispute Resolution as "Win-win Solution”.............. 97

C. The Role of Civilian Police (Preparing Peace Building)............ 99

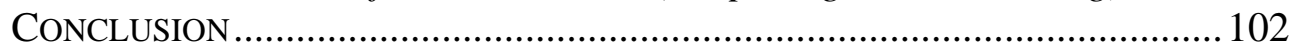

\section{INTRODUCTION}

\section{A. Chronological}

This conflict also called "Balinuraga Conflict". It began on Saturday night, October 27, 2012, when two teenage girls from Agom village, Nu (19 years old) and Em (18 years old), who passed Balinuraga village, fell from the motorcycle. According to them, they fell because plagued by a number of youths who ride bicycles in the Balinuraga village street. A midwife referred the victims, who seriously injured, for treatment to a local hospital. The peace process is already detained with the convergence of the victim's father, the chief of Balinuraga village and the youth representatives. Meanwhile, the term of the agreement for the hospital costs and indemnity cost payment has not been resolved thus far. Therefore, it was causing victim families' displeasure and anger of the youth of Balinuraga.

Due to the absence of responsibility sense from Balinuraga youth and no peace agreement between them, the victim families' and several young adult males from the Agom village meet Balinuraga youth by bringing the issue of sexual harassment. The arrival of the Agom is defined by Balinuraga youth as the "attack" so that they were already developed by a number of spears and sharp weapons. Fighting was not inevitable, Agom who did not fix themselves, become the victim in this conflict. Four people were killed on Sunday, October 28, 2012 at 03:00 am; namely Yahya, Marhadan, Alwi and Ramli, and all the victims were from the Agom.

In fact, the local police had already known about fight between Agomand Balinuraga villagers which caused four Agom death. They have done pursuit and arrest of Balinuraga youth who do kill in fighting. The police also put personnel at the location precisely to guard in case. On the other hand, information of Agom killed spreadly in the area of Agom's neighboring villages who incidentally was same tribes with Agom villager. Regional issues and no respect of Balinuraga residents against the indigenous population around, getting to the emotions of Agom and neighbor villager mostly eager to revenge attack. So that, on Sunday dawn, thousands of people, then pile up and attacked Balinuraga village. The 
Balinuraga village atmosphere was tense, anxious, number of houses charred burnt. Mass vent their emotions by destroying and burning everything they encountered.

Actually, Agom attacks had already foreseen by the police through help of three squads of Brimob (police mobile brigadier), simply due to the amount of disproportionately security forces compared with the amount of mass, Agom was still capable to enter the Balinuraga village. Knowing outnumbered, police urged Balinuraga residents to evacuate and live safely. There were close to eight houses razed to the ground by fire on that Sunday. Mass of Agom was carrying weapons ranging from machetes, swords, blades, sickles, and even an air rifle. They held not only blockaded the main road track of middle Sumatera that passing between the two villages, but also create grid locked to the traffic jam.

The security forces acted quickly by adding as many as 600 members of the Brimob from Lampung Regional Police, assisted by the military and police to keep both the villages. The police and local government responded quickly to reconcile the two parties by collecting community leaders. The peace effort was guided directly by the Chief of Lampung Regional Police. In addition, the police also ran directly to the citizen groups to provide a peaceful charm.

Apparently, the meetings between the community leaders from the two villages have no effect. Violence actions between residents resumed on Monday, October 29, 2012, at 14:00 pm. Hence, death victims increased from 10, become 14 people. A second dispute occurred because the Agom was not gratified with their revenge for Balinuraga. They entered Balinuraga village and passed plantations and paddy fields, which did not maintain by the constabulary and military. Most of the dead bodies were lying in plantations and rice fields and were apart by sharp and blunt weapons. A few hours afterward, the attacker left devastated Balinuraga village. The total of 166 units of houses in Balinuraga and Sidoreno village, 11 motorcycles, a minibus, two jeeps and a school were burnt.

In anticipation of a rising number of victims, the stakeholders try to evacuate approximately 192 households to the State Police School Kemiling and hundreds of others to Resort Police at South Lampung. The majority of refugees were women and children. They were afraid and avoided getting the victims of conflicts. The dispute on Monday, October 29, 2012 was the final showdown for the two villages, although many villagers of Agom watch while holding a sharp weapon on the borders of the village because there were issues of Balinuraga got to revenge. The security forces deployed more than 1,000 police personals, army and special forces to guard the 
border villages, roads and both areas. Furthermore, peace effort continues to be held by the government, police and community leaders.

\section{B. Completion}

Originally, the peace process had been performed before larger conflict occurred. Informal reconciliation for motorcycle accident had undertaken by the family and those who allegedly participated in the accident, but the meeting did not progress to the level of understanding. The arrival of the victim's families in the Balinuraga village had translated differently by several actors of Balinuraga, then led the battle which caused the death of Agom. Based on that situation, the issue of sexual harassment and lack of mutual respect between the two villages has grown into big ethnics war in two days.

The reconciliation process continued, directly run by the Chief of South Lampung assisted by the Resort Police of South Lampung, the National Military, community leaders of two parties and religious leaders representing of both ethnics. Meanwhile, the first process of negotiations had reached a dead lock, both villages wanted to separate from each other. The government considered that the mass population displacement should be organized with the central government and it will need quite a long time considering the facilities, funds and place itself. However, within five times of negotiations, precisely at the Novotel Hotel, Bandar Lampung, attended by the Chairman of MPAL (Indigenous Council Lampung), Kadarsyah Irsa, and custom leaders of Bali tribe, Shri I Gusti Ngurah Arya Wedakarna MWS, both parties find points of agreement that will be formulated in the following meetings.

On November 4, 2012, at Keratun Hall, Bandar Lampung, ten representatives of community leaders, both from Agom and Balinuraga villages signed the peace agreement. The Secretary of Lampung Province and the Secretary of South Lampung District witnessed the peace agreement. The peace agreement announced and socialized formally on November 17, 2012 at the center of Agom village, which attended by both villagers of Agom and Balinuraga. The government of South Lampung district also officially spread out 10 points of peace agreements to 17 sub-districts in South Lampung.

The 10 points of the peace agreement consist of;

1. Both parties agreed to maintain the security, harmony, unity and peace among the tribes of the Khagom Mufakat as the philosophy of South 
Lampung support the implementation of development programs in Republic of Indonesia.

2. Both parties agreed not to repeat the anarchic actions on behalf of the tribe, religion and race, which will cause anxiety, fear, hatred, and loss of material, particularly in both tribes and wider community.

3. Both sides agreed if there are social conflicts, fights, and disputes caused by personal problems, groups, and/or class in order to be resolved instantly by the honorable person, group leadership and/or leadership group.

4. Both sides agreed when honorable person, group leadership and/or leadership group are not capable to solve the problems as listed in point three, it will be a discussion, consensus and kinship by community leaders, traditional leaders, spiritual leadership, youth leaders local and government officials.

5. Both sides agreed when solving problems as listed in point three and four is not reached, then the community leaders, traditional leaders, religious leaders, youth leaders and local government officials conduct village turned over the matter to the authorities to be processed in accordance with the legislation in law.

6. If found guilty of unscrupulous citizens whose acts, words and efforts with potential effects of hostilities and unrest, the first and/or second party is willing to provide guidance to those concerned, and if coaching is not successful, then given traditional sanctions such as eviction against these people of South Lampung regency.

7. Liability sanctions referred to in point six shall likewise give to citizens of the South Lampung, including other tribes that exist in South Lampung regency.

8. With the problems occurred between the ethnic on October 27-29, 2012, which causes death or the victims who were injured and material loss, both sides agreed not to conduct any litigation, evidenced by a statement from the victim's families, and this also applies to police officers.

9. The tribal communities of Balinese, especially in the Balinuraga village should be able to socialize and peaceful coexistence with all society, citizen, which is in the territory of South Lampung especially with adjacent communities and/or adjacent to the field of the Balinuraga village and Way Panji District.

10. Both parties agree obliged to disseminate the contents of this peace treaty with their communities.

Apart from the 10 points of the peace agreement, the Government of South Lampung district also constructs Relations Forum, which comprises of community leaders from representative villages in each sub-district, with 
the aim of preventing any other social conflicts that might come in the future.

\section{Restorative JustiCE AND AlteRnative DisPute RESOLUTION IN ETHNiC}

\section{CONFLICT}

\section{A. Restorative Justice Approach Is Solution for Social Conflict}

Restorative justice adopted in a dispute resolution process, whereby all the parties associated with a particular criminal act, jointly solves the problems, and how to deal with due to the next or the future implications. ${ }^{2}$

In the period of post Independence Day of Indonesia, justice interpreted as retaliation, which is completely determined by the person or the aggrieved parties. Sometimes, it gives unfair condition to the offenders. They often cannot argue what they want. Frequently, justice is only providing for the victims and disturbs security and unfair society relationship.

Intended for security and order in the community, then arises "Compositie Stelsel" (composition system), which is obligatory for adverse (criminals, murderers and so on) to do a "redemption mistake" by giving compensation or penalty to the aggrieved person. On the other hand, they also required paying fines for the affected communities (in the case of the killing) to restore the justice in the society. ${ }^{3}$

Initially, the amount of the fine is determined depending on the wishes of the aggrieved parties, but then controlled and settled by the authorities. Thus, the "punishment" has begun to be developed towards the nature of public law, which is based on the interests of society and the duty or ruled authorities. ${ }^{4}$ Furthermore, the authorities forbade the aggrieved person direct retaliation against the culprits, because they have competent to make such punishment. The establishment of the penal code and regulations was evidences of ruling authority.

Customary law, which had been applied to resolve a variety of social conflict in Indonesia, has proven that settlement by involving offenders,

\footnotetext{
${ }^{2}$ Restorative justice adopted by the working group of juvenile justice of The United Nations and Basic Principles on the Use of Restorative Justice Programs in Criminal Matters 2000. See at Marshall, T. F., Research Development and Statistic Directorate, Restorative JustiCE AN Overview (London 1999); see also, Handbook of Restorative Justice (Van Ness, D. W., \& Johnstone, G. eds., Oxon OX14 4RN, Routledge Taylor \& Francis Group 2007).

${ }^{3}$ Nawawi A. B., Beberapa Aspek Kebijakan Penegakkan dan Pengembangan Ilmu Hukum PIDANA (Bandung, Citra Aditya Bakti 1998).

${ }^{4}$ Zehr, H., \& Gohar, A., The Little Book of Restorative Justice, UnI GRAPHICs (e-book 2003). Available at www.goodbks.com.
} 
victims and communities as well as community leaders, felt succeed given more sense of justice among the masses. In the process of disputes arising in the society, the emphasis on recovery efforts of community relations encourages the re-establishment of communication in society and improves harmonious relations society of damaged caused by the violator or the offender. A process involving all parties is then well known with restorative justice, which is more prioritizing in the deliberation of justice for all sides. ${ }^{5}$

The Indonesian law has not fully regulated yet about restorative justice, thus, the purpose of punishment which adopted is still aiming for revenge or intimidation, even if the organization has been adopted for rehabilitation, it accents the actors alone, not emphasizing rehabilitation or improvement of relationships with their communities, including the rehabilitation of victims. Nevertheless, we can solve particular cases with the restorative justice approach by diversion, which redirects the handling of juvenile cases that are alleged to have committed a criminal act from the formal proceedings to a special court with or without the requirements. ${ }^{6}$ Through the legalization of the juvenile justice system, ${ }^{7}$ the Indonesian government tried moreover to find fairness to all parties.

Essentially, restorative justice approach already exists in the Indonesian customary law, which is the right principle that can be utilized in the resolution of cultural conflicts. The resolution of cases with prioritizing the desire of the parties and practicing traditional law is the fastest step in accommodating the needs of the parties. Resolution processes based on traditional laws and customs have a stronger morally effect rather than the Indonesian positive law that is sometimes felt to give beneficial justice for the offender/loser. The principle of restorative justice seeks to minimize and eliminate injustice among the conflicting parties.

\section{B. Alternative Dispute Resolution as "Win-win Solution"}

Generally, the settlement of disputes outside the court or non-litigation only applies to the cases, which classified as civil matters. It is well known as ADR, "Alternative Dispute Resolution"; or "Appropriate Dispute Resolution". According to the legislation in Indonesia, principally, the criminal case cannot be settled out of the court, although in certain cases,

\footnotetext{
${ }^{5}$ Critical Issues in Restorative Justice (Zehr, H., \& Toews, B. eds., London WC2E 8LU, Lynne Rienner Publisher 2010), see also Sorsby, A., Robinson, G., \& Shapland, J., Restorative Justice IN PRACTICE (OX14 4RN, Routledge Taylor \& Francis Group 2011).

${ }^{6}$ Restorative Justice fOr Juvenile: Potentialities, Risk and Problems (Walgrave, L. ed., Leuven B-3000, Leuven University Press 1998).

${ }^{7}$ Indonesian Juvenile Justice System Act, No. 11, 2012.
} 
like juvenile cases, it is permitted the completion held outside the court. Yet, in reality, we may find out criminal cases resolved through mechanisms outside the courtroom or penal mediation. ${ }^{8}$

Penal mediation has been recommended in the documents of the United Nations, including for criminal matters containing elements of fraud and white-collar crime or if the defendant is a corporation (A/CO NF.169/6) and restorative justice (A/CONF. 187/8). Later referred in the "Penal Reform International Conference", that the most important key to criminal law system reform is enriching the criminal justice system with formal or informal mechanism system for dispute resolution in accordance with human rights.

The settlement out of the courtroom/mediation panel is considered as a positive impact, such as: (i) Providing a sense of justice to the victims and offenders or their families, (ii) preventing resentment for the parties involved, (iii) creating a harmony in social relationship considering justice for the society and victims, and (iv) participating police, prosecuting attorneys and judges in resolving conflicts, especially if a dispute happens in rural areas or geographically inaccessible. Instead, other purposes are to reduce stagnation or accumulation of cases in the court and to simplify the judicial process.

Although, alternative dispute resolution of criminal cases has not fully yet set in statue of law, there are some number of acts which are partial and limited set about discretionary authority, such as; The Chief of Police Statute No. Pol: B/3022/XII/2009/SDEOPS, December 14, 2009 on the Handling of Cases through Alternative Dispute Resolution (ADR) and National Police Chief, Regulation of Indonesia No. 7, 2008 on Basic Strategy Guidelines and Community Policing implementation of Police Task.

Based on that regulation, there are several steps for managing cases through ADR, specifically:

1. Promoting the concept of ADR in resolving criminal cases which have less material loss.

2. Resolution of criminal cases using ADR should be accorded by the litigant parties, but if there is no agreement finalized, it will apply professionally and proportionately in accordance with the legal procedures.

3. Resolution of criminal cases using ADR should be based on consensus principle and known by the local community (government representative of the neighborhood). 
4. Resolution of criminal cases using ADR should respect the social norms/customs or traditional law and fulfill a sense of justice

5. Empowering members of the Community Police Officer and community representative in identifying minor criminal cases, which hold less material loss and support the resolution through ADR concept.

6 . For cases that have been resolved through ADR concepts should not be affected by other legal actions that counterproductive to the purpose of community policing.

Implementing the Alternative Dispute Resolution on the criminal cases is expected to devote space for local institutions' participation, (customs agencies, youth organization and cultural group) and create harmony among communities, government and police through a number of dispute resolution is performed together.

\section{The Role of Civilian Police (Preparing Peace Building)}

\section{Central Role on Management Conflict}

Correlated to social conflict prevention, Indonesian National Police creates a civilian police as the representative its institution in society. Civilian police is also well known with community police. Essentially community police is an institutional strategy, which supports the systematic use of partnership and problem-solving techniques to proactively address the immediate conditions that give rise to public safety issues such as crime, social disorder, and fear of crime. Practically, community police is not run from police department itself, but also it needs the participation of the local resident. ${ }^{9}$ Creating partnership between officer and local community can be easily to detect symptoms in society that will be leaded the conflict. Generally, community police officers are representative of District Police Department. They placed in the smallest community like village or subdistrict.

Indonesian known community police officer with babinkamtibmas, ${ }^{10}$ which means a police officer who served the society to build peaceful environments, including the completion of a conflict between citizens, empowering and controlling role of exist social institutions as a forum for conflict resolution. Furthermore, Indonesian National Police have to educate their officers before certainly dive to the society. The police officers must

\footnotetext{
${ }^{9}$ Chief of Indonesian Police Decree No. Pol. Skep/737/X/2005, October 13th, 2005 on Strategy and Policy of Community Policing in Society.

${ }^{10}$ Lihawa, R., Understanding Community Policing (Memahami Perpolisian Masyarakat) (Jakarta, YPKIK 2005).
} 
have the knowledge and anxiety of local wisdoms, customs and existing traditional law for building people's confidences, creating secure and peaceful life and helping the society to resolve their own conflict with harmony. Hence, the officer has better ability to perform mass insulation in critical phase when the conflict took place.

However, the casualties of victims in Balinuraga Conflict in South Lampung become a valuable fact which can be learned by the government and the Police Department. It was about how importance of the early detection system of conflict prevention from community police officer. Supposedly, if community policing in Balinuraga village might function in the right path, then the physical violence can be turned away. Unfortunately, the police was late pulling early detected. Officially, the early detection system is one scheme of community policing strategies in identifying potential problems; analyzing, and finding solutions to prevent the conflicts becoming bigger. Therefore, Police capability should be coupled with the ability to make quick decisions in preventing, terminating and recovering the conflict.

\section{Cultural Approach by Civilian Police}

\section{a. Proactive}

Proactive activities (early warning systems) start with "early actions", "indirect prevention" and "direct prevention". These activities include identifying, recognizing and preventing the potential issues before becoming huge social conflict. Police officer, society and local/traditional leaders become the subject in organizing and implementing these programs. Generally, the principles of proactive actions are always based on community oriented, respecting the differences and diversity, upholding the law and human rights, supporting communication and transparency, preventing and protecting while enhancing the citizen knowledge of themselves and its environment. Meanwhile, there has been actualization and implementation of Pancasila ${ }^{11}$ values of community policing and the society itself. The values reflected in respecting differences and diversity, living in harmony with different religions and beliefs, increasing of solidarity and loyalty to fellow citizens, obeying human rights, awareness and equality of law.

\footnotetext{
${ }^{11}$ Pancasila is the official philosophical foundation of the Indonesian state. Pancasila consists of two Old Javanese words (originally from Sanskrit), "panca" meaning five, and "sila" meaning principles. It comprises five principles held to be inseparable and interrelated.
} 


\section{b. Partnership}

The initial concept of partnership in community policing strategy is a working relationship between the police and the public society. Police officers cannot work alone in producing and improving a secure and peaceful condition. Considerably, society, traditional leader, the government and police should be cooperation to create an additional strategy in maintaining a peaceful life in one community ${ }^{12}$. According to Trojanowich, ${ }^{13}$ community policing encourages a new partnership between people and their police, which rests on mutual respect, civility and support. Thus, clearly necessary to sustain a partnership between police and community, synergy, mutual aid, mutual esteem, reciprocal regard and tolerate each other.

FKPM $^{14}$ (Police and Community Partnership Forum) is an institution, organization or meeting place between the police and the community to discuss, learns and exchange ideas freely related to social problems in the community, especially security and justice issues. ${ }^{15}$ The Police Guidelines of Establishment and Operationalization Community Policing ${ }^{16}$ explain about the members of FKPM, which should consist of citizen and government' elements. The components can be village leaders, religions representative, ethnic leaders, youth leaders, police and government. Hence, they task for instance:

a. Collecting data, identifying problems and learning elements of society (demography map of village/city, topography map, criminality map, traffic map and police route patrol).

b. Supporting proportional measures in accompanying police performing its functions.

c. Discussing social problems sourced from inside or outside the community.

d. Monitoring community activities continuously.

e. Accommodating and accepting complaint or criticises from resident related to violation/crime and police problems in general.

\footnotetext{
${ }^{12}$ Lederach, J. P., Building Peace: Sustainable Reconciliation in Divided Societies (DC 20036-3011, United States Institute of Peace Press 1997).

${ }^{13}$ Trojanowicz, R. \& Bonnie B., Community Policing: How to Get Started (Second Edition, Cincinnati, OH, Anderson Publishing Co. 1998).

${ }^{14}$ FKPM (Forum Kemitraan Masyarakat dan Kepolisian) is Police and Community Partnership Forum. It is located in District Police Department. It has purpose to empower the society in creating peaceful condition in community.

${ }^{15}$ Police Regulation No. Pol: 31, 2006 on Mechanism of Public Opinion Polls.

${ }^{16}$ The Chief of Indonesian Police Decree No. Pol. Skep/433/VII/2006, July 1st, 2006 on Guidelines of Establishment and Operationalization Community Policing.
} 
f. Analyzing and finding the solution through mediation and consolidation based on restorative justice

g. Determining or concluding the issue together with citizen (offender and victims) and police. The resulting decision should be fair and justice for all parties and environment.

\section{c. Problem Solving}

Essentially, problem solving strategy used by police to encourage citizen in participating with the police to solve the social problems. In the context of community policing strategy, police develop soft way strategy in empowering the local community or society to resolve societal problems. Practically, it has to base on local wisdom, societal conventions/traditional law, restorative justice and the positive law. ${ }^{17}$

Thus, problems solving is not simply enough to report or handle the case, but also finds the source of the conflict as consideration to terminate it. FKPM should be an agent, mediator, arbitrator and promoter to identifying and understanding the background of the problems, gathering all the conflict parties, describing some of the best settlement options, up to the last option of law enforcement.

\section{CONCLUSION}

Balinuraga conflict happened between Lampungnese and Balinese in South Lampung. It was caused many victims, 10 people died and hundred of houses burned. Hundreds of Balinuraga's citizen, including children and women evacuated to safer places by the Police and Local Government. Actually, the conflict resolution has been performed to reduce conflict issues, but oppositely, provocation close to honor abuse and sexual harassment led the conflict growing up to massive physical contact. It occurred twice in the boarder of both villages. By deploying thousands of police officers and military personnel in the villages, fighting can be closed up and dissolved.

Settlement process was done by mediation and reconciliation. It involved South Lampung's government, District Police Department and community leaders from both parties. This step required by the government as it purports to bring out justice, accommodate the interest and needs of

\footnotetext{
${ }^{17}$ Suparlan, Memantapkan Kepemimpinan Polri Guna Akselerasi Strategi Polmas Dalam Rangka Mewujudkan Keamanan Dalam Negeri, Paper for National Seminar, Sespati Polri Dik. Reg. Ke-13 and Pasis Sespim Polri Dik. Reg. Ke-45 TA 2007.
} 
each community. Thus, both parties with sincere and responsibility can implement the agreement.

The government used restorative justice and win-win solutions principles in solving the conflict. As the result of ethnic conflict resolution, there were four key points: Citizen contract, cultural area, citizen empowerment, and community policing. These four dimensions are expected to be capable of establishing a united community with the surrounded of peace and pluralism. 